\title{
Еколого-гігієнічні проблеми сучасного харчування спортсменів. Шляхи вирішення
}

\section{удк 614.7:612.3:796 \\ О. І. Циганенко, Я. В. Першегуба, Н. А. Склярова, Л. Ф. Оксамитна}

\author{
Національний університет фізичного виховання і спорту України, Київ, Україна
}

\begin{abstract}
Резюме. Мета роботи - на основі аналізу джерел наукової інформації визначити шляхи вирішення еколого-гігієнічних проблем сучасного харчування спортсменів. При проведенні досліджень використані методи теоретичного аналізу літератури: узагальнення, синтез, формалізація, абстрагування. Аналіз наукової літератури та інших джерел інформації показав, що еколого-гігієнічні проблеми харчування спортсменів полягають у тому, що під час складання харчових раціонів спортсменів:

- не враховуються екологічні типи харчування;

- недостатньо використовується харчування як засіб підвищення природної екологічної стійкості організму спортсменів до несприятливих чинників навколишнього середовища;

• не контролюється надходження з їжею токсичних речовин;

- відсутні фахівці-екологи, які спільно зі спортивними лікарями і дієтологами впроваджували б у практику положення екології харчування в сфері спорту.

Запропоновано системний підхід, який включає: врахування екологічних типів і можливостей харчування як фактора підвищення екологічної природної стійкості організму спортсмена до дії природних небезпечних чинників; обмеження надходження до організму спортсменів токсичних речовин з їжею за рахунок ширшого використання продукції екологічного (біологічного) землеробства; використання харчування для профілактики та лікування десинхронозу; можливість вивчення дисципліни «Екологія харчування у сфері спорту» у рамках магістратури за спеціалізацією «Екологія фізичної культури і спорту».

Ключові слова: екологія, спорт, харчування, адаптація, стійкість.
\end{abstract}

\begin{abstract}
Резюме. Цель работы - на основе анализа источников научной информации определить пути решения эколого-гигиенических проблем современного питания спортсменов. При проведении исследований использованы методы теоретического анализа литературы: обобщение, синтез, формализация, абстрагирование. Проведенный анализ научной литературы и других источников информации показал, что существует эколого-гигиеническая проблема питания спортсменов, состоящая в том, что при составлении пищевых рационов спортсменов:

- не учитываются экологические типы питания;

- недостаточно используется питание как средство повышения природной экологической устойчивости организма спортсменов к неблагоприятным факторам окружающей среды;

- не контролируется поступление с пищей токсических веществ;

- отсутствуют специалисты-экологи, которые совместно со спортивными врачами и диетологами внедряли бы в практику положения экологии питания в сфере спорта. Предложен системный подход, включающий: учет экологических типов и возможностей питания как фактора повышения экологической природной устойчивости организма спортсмена к действию природных опасных факторов; ограничение поступления в организм спортсменов токсичных веществ с пищей за счет более широкого использования продукции экологического (биологического) земледелия; использование питания для профилактики и
\end{abstract}


лечения десинхроноза; возможность изучения дисциплины «Экология питания в сфере спорта» в рамках магистратуры по специальности «Экология физической культуры и спорта».

Ключевые слова: экология, спорт, питание, адаптация, стойкость.

Abstract. Objective of work - to determine the ways for solution of ecological and hygienic problems of athlete nutrition on the basis of scientific literature analysis. The following methods of literature theoretical analysis have been used: generalizations, synthesis, formalization, abstraction. The analysis of scientific literature and other sources of information showed that there is ecological and hygienic problem of athletes' nutrition, consisting in the fact that during preparation of food rations of athletes:

- ecological types of nutrition are not accounted;

- nutrition is insufficiently used as a means for enhancing natural ecological stability of athletes with respect to unfavourable environmental conditions;

- dietary intake of toxic substances is not controlled;

- there are no environmental specialists, who could introduce the provisions of nutrition ecology in sports sphere together with sports physicians and dieticians.

Systematic approach has been suggested including: account for ecological types and potentials of nutrition as a factor enhancing ecological natural body stability to the actions of natural dangerous factors; restriction of dietary intake of toxic substances at the expense of wider usage of ecological products; usage of nutrition for preventing and treating desynchronosis; possibility of studying «Nutrition ecology in sport» subject in the magistracy in «Ecology of physical culture and sport» specialty.

Keywords: ecology, sport, nutrition, adaptation, resistance.

Вступ. Сучасний спорт, як і інші сорери діяльності людини, суттєво залежить від екології харчування, ступеня його екологічності. Під екологічністю харчування розуміють його відповідність екологічному типу харчування конкретної людини та екологічному стану довкілля, потребам і безпеці людини, характеру ії професійної та суспільної діяльності [5, 8, 10, 12, 20, 22].

Харчування розглядають як головний керований екологічний чинник, який забезпечує нормальний розвиток, здоров'я та якість життя людини, її працездатність, у тому числі фрізичну, довголіття, розвиток творчого потенціалу, спроможність до занять спортом і фрізичною культурою $[2,4,5,7,13,16,20]$.

Від ступеня екологічності харчування залежать такі екологічні можливості людини, як стійкість до негативних і небезпечних чинників довкілля, спроможність до виживання в екстремальних умовах, фрізична працездатність, витривалість, силові можливості, швидкість та якість відновних процесів в організмі, що надзвичайно важливо у сорері сучасного спорту. Саме тому основним принципом в екології харчування став принцип його екологічності $[5,8,15,20]$.

Водночас, існує проблема досягнення екологічності харчування, насамперед у сфері спорту. Особливо це стосується організації харчування під час проведення міжнародних змагань, у яких беруть участь спортсмени з різними екологічними типами харчування. Невирішеність цієї проблеми спричинена відсутністю системного підходу до реалізації положень екології харчування у сфрері спорту, що зумовлює актуальність розроблення такого підходу.
Зв'язок роботи 3 важливими науковими програмами або практичними завданнями. Дане дослідження пов'язане 3 важливим практичним завданням, а саме розробкою програми навчальної дисципліни «Екологія харчування та харчових продуктів» при підготовці магістрів за спеціальністю 017 «Фізична культура і спорт» спеціалізація «Екологія фрізичної культури і спорту».

Мета роботи - на основі аналізу джерел наукової інформації визначити шляхи вирішення еколого-гігієнічної проблеми сучасного харчування спортсменів.

Методи i організація дослідження. Відповідно до поставленої мети було проведено системне дослідження наукової літератури. На його основі проаналізовано еколого-гігієнічні проблеми харчування спортсменів та визначено шляхи їх вирішення. Під час проведення досліджень використано методи теоретичного аналізу літератури: узагальнення, синтез, формалізація, абстрагування [9].

Результати дослідження та їх обговорення. Проведений аналіз наукової та науково-методичної літератури показав, що сучасний спорт представлений спортсменами 3 різних контингентів і країн світу, які поділяються на двадцять екологічних типів харчування за такими основними показниками, як основна зернова культура, основне джерело енергії, основне джерело білка. Зазначене потребує враховувати екологічні типи харчування під час складання харчових раціонів спортсменів $[4,5,13,15]$.

Більшість спортсменів України, Східної та Північної Європи, США, Канади, Чилі, Уругваю, Аргентини, Австралії, Нової Зеландії, європейське запоходженням населення Південно-Афрриканської 
Республіки належать до першого екологічного типу харчування. Основні зернові культури - жито, пшениця; основне джерело енергії - вуглеводи рослинного та жири тваринного походження; основне джерело білка - свинина, яловичина, молоко та молочні продукти [5].

Для спортсменів Бразилії (окрім басейну річки Амазонка) - країни, де проходили Олімпійські ігри 2016 р., характерний п'ятий екологічний тип харчування. Основні зернові культури - кукурудза, рис, пшениця; основне джерело енергії харчова продукція зі значним вмістом цукру; основне джерело білка - бобові культури [5].

Для спортсменів Північно-Східної Індії характерний сьомий за класифрікацією екологічний тип харчування з наявністю такого напрямку у харчуванні, як вегетаріанство. Основна зернова культура та основне джерело енергії - рис; основне джерело білка - бобові культури [5].

Для корінних мешканців віддалених районів Арктики характерний значний відсоток вживання їжі тваринного походження, екологічний тип харчування - двадцятий. Основна зернова культура пшениця, яку завозять 3 інших регіонів; основне джерело енергії - жир диких тварин і риби; основне джерело білків - риба та м'ясо диких тварин [5].

Екологічна адаптація людини, а відповідно і спортсменів, до різних екологічних типів харчування реалізується на популяційному рівні. Під екологічною адаптацією розуміють пристосування організмів до різних екологічних умов і чинників, у тому числі до різних типів харчування на популяційному рівні, яке було вироблене в процесі екологічного розвитку. Це ж стосується людини як складової всього живого на планеті Земля [4, 5, 20, 23, 25].

Екологічне пристосування організмів, у тому числі організму людини, до різних умов і чинників довкілля на популяційному рівні відбувається за такими основними напрямками: генетична адаптація, морфологічна адаптація, фрізіологічна адаптація та біохімічна адаптація. Розрізняють такі групи екологічних адаптаційних процесів: мутаційна адаптація, модифікаційна адаптація, модуляційна адаптація [4, 5].

У результаті тривалого еколого-біологічного пристосування різних популяцій людини сорормувався адаптивний тип, що включає утворення специорічних анатомо-фрізіологічних механізмів, які забезпечують найкраще використання наданих на певній території харчових ресурсів [5].

Така екологічна популяційна адаптація призвела до появи своєрідних варіантів шлункового травлення у представників різних груп сучасного людства. Для більшості популяцій людини характерне травлення за так званим типом кабана (змішаний тип харчування), при якому перетравлення харчової грудки відбувається переважно поблизу стінок шлунка під впливом секрету травних залоз. Кислотність шлункового соку порівняно невисока. Для популяцій корінних мешканців Арктики, раціон яких містить дуже велику кількість м'ясопродуктів і тваринного жиру, характерне шлункове травлення за типом вовка - аналогічне типу травлення хижаків. У цьому разі хімічне оброблення їжі відбувається у центральній частині шлунка на тлі високої кислотності травного соку. Для захисту слизової оболонки шлунка від впливу кислоти його клітини виробляють велику кількість слизу, що запобігає виникненню виразок. Більше того, у деяких представників аборигенних народів Південно-Східної Азії виявлено постійну мікрофрлору, яка фріксує азот (азотфіксуюча мікрофрлора), що $є$ характерною для таких травоїдних тварин, як велика рогата худоба [5].

Під час складання харчових раціонів спортсменів важливою $€$ індивідуалізація харчування з урахуванням його екологічного типу. Для цього використовують спеціальні інформаційні комп'ютеризовані програми, які дають можливість цілеспрямовано відбирати основні продукти харчування відповідно до екологічного типу харчування (основна зернова культура, основне джерело енергії, основне джерело білка).

При організації харчування спортсменів з метою врахування екологічного типу харчування додатково можуть бути використані можливості спеціалізованих закладів громадського харчування - національної кухні (японська, китайська тощо), тому що національні кухні народів світу за своєю суттю відображають не тільки етнографічні особливості харчування населення, але й певною мірою відповідні екологічні типи харчування. Це можливо за умови, що вони за наявним асортиментом страв і продуктів харчування адекватні меті та задачам тренувально-змагального процесу.

Крім проблеми формування та реалізації адаптивного типу харчування для спортсменів має значення проблема використання харчування для посилення екологічної стійкості до несприятливих чинників навколишнього середовища.

Під екологічною стійкістю організму розуміють природні видові властивості організму тварин і рослин, що дозволяють ефективно протистояти дії несприятливих природних чинників довкілля: високій та низькій температурі повітря, значним перепадам тиску у водному середовищі й атмосорерному повітрі тощо. Екологічну адаптацію, екологічну стійкість і здатність до репродукції розглядають як три основні складові можливості 
виживання всіх біологічних видів на планеті Земля. Екологічна стійкість має ключове значення для людини як соціально-біологічного виду, тому що саме завдяки їй значною мірою забезпечується найдовша тривалість життя людини порівняно 3 іншими представниками класу ссавців $[5,19,21]$.

Екологічна стійкість до несприятливих природних чинників довкілля може бути посилена шляхом використання положень ергогенної (ергогенічної, енергетичної) дієтетики та ії програм, із застосуванням спеціального програмного (системного) підходу посилення енергетичної спроможності організму людини, у тому числі спортсменів $[17,18]$.

Стійкість організму спортсмена до різних несприятливих екологічних умов можна суттєво підвищити шляхом використання спеціальних положень і програм спортивного харчування ергогенічної спрямованості (максимальне забезпечення енергетичного ресурсу організму). До несприятливих екологічних умов довкілля, які впливають на організм спортсмена, відносять дію низьких і високих температур повітря, охолоджувальну дію високої швидкості руху повітря при низьких температурах повітря і високій вологості, умови високогір'я. Для оцінки впливу цих умов проводиться розрахунок енергетичних витрат і такого показника, як вітро-холодовий індекс. Використання програм спортивного харчування енергетичної спрямованості може суттєво підвищити стійкість до складних екологічних умов печер з їх високою вологістю і низькими температурами та 3 подальшою адаптацією організму до звичних умов рівнинної місцевості, до несприятливих екологічних умов, які виникають на глибині при глибоководному зануренні, та досягнення подальшої нормалізації фрункцій шлунково-кишкового тракту аквалангіста, які можуть порушуватися внаслідок дії високого тиску води. Потрібно враховувати особливості енергетичних витрат відповідно до енергетичної цінності харчового раціону в «арідних» і тропічних зонах для «умовного європейця» (жителя помірної зони), які для нього вже $\epsilon$ екстремальними, наприклад, умови зони тропіків Бразилії $[6,11]$.

Для підвищення стійкості організму спортсмена в складних умовах високогір'я може бути використана спеціальна програма ергогенічної дієтетики - програма стимуляції гемопоезу та витривалості для спортсменів, яка дозволяє знизити ризик виникнення гострої та хронічної гірської хвороби, розвитку гіпоксії та підвищити рівень фрізичної працездатності і витривалості $[17,18,24]$.

Зазначене особливо актуально для екологічно-екстремальних видів спорту, таких, як високогірний альпінізм (вище 5800 м над рівнем моря), глибоководний спортивний дайвінг (глибше 40-50 м від рівня води водойми), спортивна спелеологія тощо $[6,11]$.

Ергогенічна дієтетика базується на таких основних принципах: принцип адекватності (насамперед адекватність поставленим меті та задачам), принцип системності (програмний підхід до вирішення поставлених мети та задач), принцип повноцінності (містить всі необхідні інгредієнти харчування), принцип збалансованості (оптимальне співвідношення основних інгредієнтів харчування), принцип індивідуальності (індивідуальний підхід до кожного спортсмена), принцип режимності (режим застосування спеціальних програм і дієт) тощо. При цьому застосовуються такі основні ергогенічні критерії, як критерій потужності (субстратний фоонд для забезпечення енергетичних потреб), критерій ємкості (відображає доступний субстратний фонд для забезпечення енергетичних потреб), критерій ефективності (відображає ефрективність використання енергіï) $[17,18]$.

Суттєвою проблемою в сучасному спорті $\epsilon$ врахування екологічної біоритмології (хронотипу) організму людини, у тому числі спортсменів. Для більшості населення планети Земля характерний саме денний екологічний тип фрізичної та психічної активності, який отримав умовну назву «голуби». Слід відзначити, що він екологічно домінує не тільки у людини, але й у всіх вищих приматів, у тому числі людиноподібних мавп. Саме при такому хронотипі найкраще реалізуються можливості кольорового бінокулярного зору людини, що дає змогу ефективно займатися складно-координаційними видами діяльності і, відповідно, складно-координаційними видами спорту в умовах світового дня [12, 15, 25].

Проте трапляються порушення біоритмології (хронотипу), насамперед гострий десинхроноз. Він може виникнути при перельотах через декілька часових поясів і спричинити погіршення спортивної форми спортсменів. Тому для профрілактики та лікування цього стану у спортсменів було розроблено спеціальну ергогенічну програму спортивного харчування - програму корекції гострого десинхронозу [16-18].

Особливе місце займає проблема еколого-гігієнічної безпеки харчової продукції та харчування спортсменів. Вона обумовлена тим, що харчовий раціон спортсменів за масою більший ніж харчовий раціон пересічної людини. Така відмінність призводить до того, що в організм спортсмена надходить більше токсичних речовин, ніж це дозволено за регламентом допустимого надходження токсичних речовин з їжею. Тому у харчуванні спортсменів рекомендується ширше використовувати продукцію екологічного (біологічного) землеробства, яка не 
містить залишкових кількостей пестицидів та інших токсичних речовин. Слід активніше запроваджувати в практику, у тому числі стосовно спортсменів, систему забезпечення безпеки харчових продуктів HACCP (Hazard Analysis Control Critical Pointis аналіз ризиків у контрольних точках) [1, 3, 19, 20].

Суттєвою проблемою $є$ відсутність фрахівцівекологів для реалізації на практиці положень екології харчування у сорері спорту спільно із лікарями спортивної медицини та дієтологами. Для їх підготовки можна використовувати магістратуру за спеціалізацією «Екологія фрізичної культури і спорту». У рамках такої магістратури поряд з іншими екологічними дисциплінами можна викладати дисципліну «Екологія харчування у сорері спорту» [14, 21].

За результатами вивчення дисципліни «Екологія харчування у сорері спорту» магістри повинні:

- знати основні положення «Екології харчування у сорері спорту», екологічної безпеки харчування та харчових продуктів; основні положення харчування людини як соціально-біологічного виду; основні екологічні типи харчування сучасної людини; особливості харчування в складних та екстремальних екологічних умовах; використання ергогенічної (ергогенної) дієтетики для посилення стійкості організму до дії небезпечних екологічних чинників довкілля;

- вміти застосовувати основні положення «Екології харчування у сорері спорту», у тому числі з метою посилення стійкості організму до дії небезпечних екологічних чинників довкілля; користуватися положеннями екологічної безпеки харчування та харчових продуктів; визначати особливості харчування в складних та екстремальних екологічних умовах; застосовувати положення ергогенної (ергогенічної) дієтетики та її програм для посилення стійкості організму спортсменів до дії небезпечних екологічних чинників довкілля, у складних та екстремальних екологічних умовах.

Висновки. 1. Проведений аналіз наукової літератури та інших джерел інфрормації показав, що існує еколого-гігієнічна проблема харчування спортсменів, яка полягає в тому, що під час складання харчових раціонів спортсменів:

- не враховуються екологічні типи харчування;

- недостатньо використовується харчування як засіб підвищення природної екологічної стійкості організму спортсменів до несприятливих чинників навколишнього середовища;

- не контролюється надходження з їжею токсичних речовин;

- відсутні фахівці-екологи, які спільно зі спортивними лікарями і дієтологами впроваджували б у практику положення екології харчування в сорері спорту.

2. Як шлях вирішення проблеми запропоновано системний (програмний) підхід, який включає врахування екологічних типів і можливостей харчування як чинника підвищення екологічної природної стійкості організму спортсмена до дії небезпечних природних фракторів, обмеження надходження до організму спортсменів токсичних речовин з їжею за рахунок ширшого використання продукції екологічного (біологічного) землеробства, використання харчування для профрілактики та лікування десинхронозу, можливість вивчення дисципліни «Екологія харчування у сорері спорту» у рамках магістратури за спеціалізацією «Екологія фрізичної культури і спорту».

Перспективи подальших досліджень. Розроблення питань ергогенічної дієтетики щодо підвищення стійкості до негативних чинників довкілля.

\section{Література}

1. АсташеВа Н. П. Основы производства экологически безопасной сельскохозяйственной продукции: учеб. пособие / Н. П. Асташева. - М. : МГАУ, 2005. - 75 с.

2. Базиян Е. Н. Экология питания в XXI веке на практике / Е. Н. Базиян. - М. : Спорт и культура - 2000, 2008. - 96 с.

3. Бегей С. В. Екологічне землеробство: підручник / С. В. Бегей. - Львів : Новий світ, 2010. - 428 с.

4. Бойчук Ю. Д. Екологічні проблеми харчування людини / Ю. Д. Бойчук, О. І. Циганенко, Е. М. Солошенко. - Черкаси : Вид-во «Вертикаль», ПП «Кандич», 2010. - 90 с.

5. Димань Т. М. Екотрофологія. Основи екологічно безпечного харчування: навч. посіб. / Т. М. Димань, М. М. Барановський, Г. О. Білявський. - К. : Лібра, 2006. - 346 с.

6. Дмитрук А. И. Медицина глубоководных погружений / А. И. Дмитрук. - СПб : ГиПГСПб, 2004. - 292 с.

7. Дубровский В. И. Экогигиена физической культуры и спорта / В. И. Дубровский, Ю. А. Рахманин, А. Н. Разумов. М. : Владос, 2008. - 551 с.

8. КозлоВ А. И. Экология питания : курс лекций / А. И. Козлов. - М. : МНЭПУ, 2002. -184 с.

\section{References}

1. Astasheva N. P. (2005) Osnovy proizvodstva yekologicheski bezopasnoi sel'skohozjaistvennoi produkcii: uchebn. posob. [Fundamentals of producing ecologically safe agricultural products: teaching guide] M.: Izd-vo «MGAU». (in Russian)

2. Bazijan E. N. (2008) Yekologija pitanija v XXI veke na praktike [Ecology of nutrition in the XXI century in practice]. M.: Izd-vo «Sport i kul'tura - 2000» (in Russian)

3. Behey S. V. (2010) Ekolohichne zemlerobstvo: pidruchn. [Ecological farming: textbook]. L'viv: Vyd-vo «Novyy svit» (in Ukrainian)

4. Boychuk Yu. D., Tsyhanenko O. I., Soloshenko E. M. (2010) Ekolohichni problemy kharchuvannya lyudyny [Ecological problems of human nutrition]. Cherkasy: Vyd-vo «Vertykal'», PP «Kandych» (in Ukrainian)

5. Dyman' T. M., Baranovs'kyy M. M., Bilyavs'kyy H. O. (2006) Ekotrofolohiya. Osnovy ekolohichno bezpechnoho kharchuvannya: uchbov. posibn. [Ecotrophology. Fundamentals of ecologically safe nutrition: teaching guide]. K.: Vyd-vo «Libra» (in Ukrainian)

6. Dmitruk A. I. (2004) Medicina glubokovodnyh podruzhenii [Medicine of deep immersions]. SPb: GiPGSPb (in Russian) 
9. Кліменко М. О. Методологія та організація наукових досліджень (в екології): підручник / О. М. Кліменко, В. Г. Петрук, М. Б. Мокін, Н. М. Вознюк. - Херсон : Олді-плюс, 2012. -474 c.

10. КозлоВ А. И. Пища людей (экология питания) / А. И. Козлов. - Фрязино : Век-2, 2005. - 272 с.

11. Лебедихин $A$. В. Основы альпинизма и скалолазания: учеб. / А. В. Лебедихин. - Новосибирск : ГОУ ВПО УГТУУПИ, 2004. - 246 с.

12. ЛыкоВ И. Н. Экология питания в экологии человека / И. Н. Лыков, Г. А. Шестакова // Известия Калужского общества изуч. природы. - Кн. 7 (сб. науч. трудов). - Калуга : КГПУ, 2006. - С. 5-11.

13. Окара А. И. Экология пищевых продуктов: учеб. пособие / А. И. Окара, Н. П. Старикова. - Хабаровск : ХГАЭП, 2002. -283 c.

14. Петрушина Н. П. Магистерская программа «Экология физической культуры и спорта» / Н. П. Петрушина, О. И. Коломиец, О. А. Макунина // Ученые записки ун-та им. П. Ф. Лесгафрта. - 2014. - № 6 (112). - С. 148-154.

15. Пища как экологический фактор: учеб. пособие / В. И. Трухачев, В. П. Толоконников, И. О. Лысенко. - Ставрополь : АГРУС, 2005. - 182 с.

16. Платонов В. Н. Система подготовки спортсменов в олимпийском спорте. Общая теория и ее практическое приложение: учеб. [для тренеров] / В. Н. Платонов. - К. : Олимп. лит., 2015. - Кн. 2. - С. 952-1059.

17. Эргогенные эфффекты спортивного питания / Н. И. Волков, В. И. Олейников. - М. : Сов. спорт, 2012. - 100 с.

18. ПортугалоВ С. Н. Программы спортивного питания в эргогенном обеспечении подготовки спортсменов / С. Н. Португалов, Н. И. Волков, В. И. Олейников, Н. А. Фудин. - М. Сов. спорт, 2012. - 60 с.

19. Циганенко О. І. Проблема регламентації харчових раціонів спортсменів, їх безпечності, шляхи вирішення / О. І. Циганенко, Н. А. Склярова // Спорт. медицина. № 2. - 2010. - С. 108-111.

20. Циганенко О. І. Проблеми еколого-гігієнічної безпеки харчування спортсменів та шляхи їх вирішення / Акт. питання гігієни та еколог. безпеки України: матер. конфр. - К., 2012. C. 207-211.

21. Циганенко О. І. Проблема підготовки фрахівців з екології для фрізкультурно-спортивної галузі. Шляхи вирішення / О. І. Циганенко, Я. В. Першегуба, Н. А. Склярова, Л. Ф. Оксамитна // Наук. часопис Нац. пед. ун-ту ім. М. П. Драгоманова. - Серія № 15 «Науково-педагогічні проблеми фрізичної культури // Фізична культура і спорт». - 2016. Вип. 03(72)16. - С. 152-156.

22. Berdus M. G. Sports ecological education and ecological sports / M. G. Berdus // Modern Olympic sports for all. Warsaw, 2002. - P. 236-237.

23. Liberman M. Ecological management : Books for University Students / M. Liberman. - Cambridg : Cambridg university press, 2004. - 207 p.

24. Jeukendrup $A$. Sports nutrition an introduction to energy production and performance / A. Jeukendrup, M. Gleeson. 2 ed. - Illinois : Human Kinetics, 2010. - 475 p.

25. Zerebylo V. D. Ecology : textbook / V. D. Zerebylo, A. M. Thereshchenko - Kyiv : ISCIS NTUU «KPI», 2008. - 176 p.

igme@ukr.net
7. Dubrovskii V. I., Rahmanin Yu. A., Razumov A. N. (2008) Yekogigiena fizicheskoi kul'tury i sporta [Ecohygiene of physical culture and sport]. M.: Izd-vo «Vlados» (in Russian)

8. Kozlov A. I. (2002) Yekologija pitanija: kurs lekcii [Nutrition ecology : lecture course]. M.: Izd-vo «MNYePU» (in Russian)

9. Klimenko M. O., Petruk V. H., Mokin M. B., Voznyuk N. M. (2012) Metodolohiya ta orhanizatsiya naukovykh doslidzhen' (v ekolohiyi): pidruchn. [Methodology and organization of scientific studies (in ecology): textbook]. Kherson: Vyd-vo «Oldi-plyus» (in Ukrainian)

10. Kozlov A. I. (2005) Pisha lyudei (yekologija pitanija) [Human nutrition (nutrition ecology)]. Frjazino: Izd-vo «Vek-2» (in Russian)

11. Lebedihin A. V. (2004) Osnovy al'pinizma i skalolazanija: uchebn. [Fundamentals of mountaineering: textbook]. Novosibirsk: GOU VPO UGTU-UPI (in Russian)

12. Lykov I. N., Shestakova G. A. (2006) Yekologija pitanija v yekologii cheloveka [Nutrition ecology in human ecology]. Izvestija Kaluzhskogo obshestva izuch. Prirody. Kn. 7 (sborn. nauchn. trudov). Kaluga: Izd-vo «KGPU», pp. 5-11. (in Russian)

13. Okara A. I., Starikova N. P. (2002) Yekologija pishevyh produktov: uchebn. posob. [Ecology of nutrition products: teaching guide] Habarovsk: Izd-vo " HGAYeP» (in Russian)

14. Petrushina N. P., Kolomiec O. I., Makunina O. A. (2014) Magisterskaja programma "Yekologija fizicheskoi kul'tury i sporta» [Master's program "Ecology of physical culture and sport"]. Uchenye zapiski universiteta im. P. F. Lesgafta, no 6 (112), pp. 148-154. (in Russian)

15. Truhachev V. I., Tolokonnikov V. P., Lysenko I. O. (2005) Pisha kak yekologicheskii faktor: uchebn. posob. [Food as an ecological factor: teaching guide] Stavropol': Izd-vo "AGRUS» (in Russian)

16. Platonov V. N. (2015) Systema podhotovky sportsmenov v olympyiskom sporte. Obshchaia teoryia y ee praktycheskoe prylozhenye: uchebn. [System of athletes' preparation in the Olympic sport General theory and its practical applications: textbook] K.: Olymp. lyter., Kn. 2, pp. 952-1059. (in Russian)

17. Volkov N. I., Oleinikov V. I. (2012) Yergogennye yeffekty sportivnogo pitanija [Ergogenic effects of sports nutrition]. M.: Izd-vo "Sovetskii sport» (in Russian)

18. Portugalov S. N., Volkov N. I., Oleinikov V. I., Fudin N. A. (2012) Programmy sportivnogo pitanija $v$ yergogennom obespechenii podgotovki sportsmenov [Sports nutrition programs in ergogenic support of athletes' preparation]. M.: Izd-vo «Sovetskii sport» (in Russian)

19. Tsyhanenko O. I., Sklyarova N. A. (2010) Problema rehlamentatsiyi kharchovykh ratsioniv sport smeniv, yikh bezpechnosti, shlyakhy vyrishennya [Problem of athlete nutrition ration reglamentation, their safety and ways of solution]. Sportyvna medytsyna, pp. 108-111. (in Ukrainian)

20. Tsyhanenko O. I. (2012) Problemy ekoloho-hihiyenichnoyi bezpeky kharchuvannya sportsmeniv ta shlyakhy yikh vyrishennya [Problems of ecologo-hygienic safety of athlete nutrition and ways of their solution]. Aktual'ni pytannya hihiyeny ta ekolohichnoyi bezpeky Ukrayiny: mater. konf. Kyyiv, pp. 207-211. (in Ukrainian)

21. Tsyhanenko O. I., Pershehuba Ya. V., Sklyarova N. A., Oksamytna L. F. (2016) Problema pidhotovky fakhivtsiv z ekolohiyi dlya fizkul'turno-sportyvnoyi haluzi. Shlyakhy vyrishennya [Problem of ecology specialist preparation for physical culture and sport sphere. Strategies of solution]. Naukovyy chasopys Nacyon. pedag. universytety im. M. P. Drahomanova. Seriya no 15 "Naukovo-pedahohichni problemy fizychnoyi kul'tury. Fizychna kul'tura i sport», vyp. 03(72)16, pp. 152-156. (in Ukrainian)

22. Berdus M. G. (2002) Sports ecological education and ecological sports Modern Olympic sports for all, Warsaw, pp. 236-237.

23. Liberman M. (2004) Ecological management. Books for University Students. Cambridg: Cambridg university press, 207 p.

24. Jeukendrup A., Gleeson M. (2010) Sports nutrition an introduction to energy production and performance. Illinois: Human Kinetics, $475 \mathrm{p}$.

25. Zerebylo V. D., Thereshchenko A. M. (2008) Ecology: textbook. K.: ISCIS NTUU «KPI». 